and their carelessness with dates on pp. 200-20I does not increase one's confidence. They have some interesting and definite opinions on milk and alkalies but seem curiously undecided about sarcoidosis, and hardly come to grips at all with the hepato-renal syndrome. The inclusion of Fig. 3 on p. 59 is pointless, but it reappears with a slightly different meaning on p. 94, though the equation it represents is misprinted on p. 93 and $K$ is said to be a constant, a statement contradicted (correctly) 4 lines later. The book is well produced but expensive.

\section{ANTIBIOTICS ANNUAL, 1958-1959}

Edited by Henry Welch, Ph.D., and Felix MartiIbaNEZ, M.D. Pp. xvii + I 107. New York: Interscience Publishers Ltd. 1959. Price 90s.

The Antibiotics Annual 1958-59 records the proceedings of the Sixth Annual Symposium on Antibiotics. The first five papers are by Sir Howard Florey and Drs. Marti-Ibanez, Waksman, Keefer and Dowling and review the historic perspective of antibiotic therapy. The remaining communications range from human disease to animal feeding. The subjects are no longer strictly confined to the laboratory testing of antibiotics and to clinical trials and reports, but now include information on new steroids and the epidemiology of hospital strains of staphylococci.

The drive for new antibiotics appears to be slackening. Combined antibiotics such as oleandomycin-tetracycline act fairly well in districts where organisms are not already resistant to one of them. Unfortunately oleandomycin shows cross resistance with erythromycin with ' trained' staphylococci but some wild strains show dissociated resistance, so the two must be tested for separately. It appears from the paper of Colville and his associates that in this group erythromycin is better than triacetyloleandomycin especially when in the form of the propionate, a preparation on which much work appears this year.

No very new developments in the systemic therapy of fungus diseases, neoplasms or viruses have been reported. The Annual gives a good survey of the growing aspects of chemotherapy.

\section{TEXTBOOK OF PHYSIOLOGY AND BIOCHEMISTRY}

By G. H. Bell, M.D., F.R.F.P.S.G., F.R.S.E., J. N. Davidson, M.D., D.Sc., F.R.F.P.S.G., F.R.S.E., and H. Scarborough, M.B., Ph.D., F.R.C.P.E. Fourth Edition. Pp. xi $+1,06_{5}$, illustrated. Edinburgh: E. \& S. Livingstone Ltd. 1958. 63 s.

B.D.S. has become a favourite among medical students studying for the second M.B. The authors have made an effort to keep the textbook up to date and the fourth edition appears only nine years after the first. Medical knowledge is advancing at such a rapid rate, especially in the fundamental and pre-clinical sciences, that it is almost impossible to encompass an adequate amount of physiology and biochemistry, even in 1,000 pages. For this reason many of the sections in this book seem incomplete. For example, the section on the respiratory blood gases is inadequate according to modern standards and still retains the outdated units of measurement of volume per cent. for $\mathrm{CO}_{2}$ content. Recent views on renal function get scant mention, although they have meant very much in the elucidation of clinical problems. The section on acid-base balance and hydrogen ion regulation is also much too short. One can only refer to one's original comment that in order to cover the whole field the authors have been obliged to leave out much. The popularity of the book stems from the fact that what is described is described well, succinctly, and accurately.

\section{CELL AND TISSUE CULTURE}

By John Paul, M.B., M.R.C.P.Ed. Pp. viii + 26r, illustrated. Edinburgh: E. and S. Livingstone Ltd. I959. 30 .

This book is welcome as an up-to-date account of techniques and applications of tissue culture. It is divided into four parts. The first describes the principles of cell culture, the second the preparation of materials, the third special techniques and the last special applications of cell and tissue culture methods. An effort has been made to incorporate some of the more important developments which have occurred in this field over the last few years.

It is a book which will be more valuable to the worker at the bench than for the reader interested in theoretical aspects of tissue culture. One of the most useful sections of the book is that which gives sources for special apparatus and equipment. Suggestions are made for the basic apparatus needed to equip a tissue culture unit. There is no doubt that this work will gain a place on the shelves of many workers engaged in the expanding field of tissue culture.

\section{SURGICAL TECHNIQUE}

By Stephen Power, M.S., F.R.C.S. Second Edition. Pp. $x+41 \mathrm{r}$, illustrated. London: William Heinemann Ltd. I959. 40s.

This little mine of information appears in its second edition thoroughly revised. It is essentially very readable but it would appear to fall in a cleft stick. Its pearls of surgical wisdom and experience are beyond the house officer, so one must conclude that it is for the registrar. On the other hand, at its price he is more likely to select a volume with broader scope. In spite of this criticism, the reader is assured that he will enjoy reading it.

늠

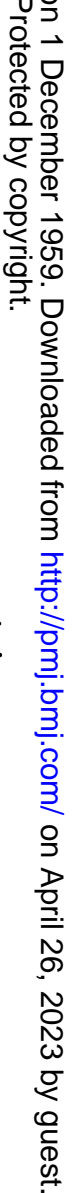

